\title{
Pemeriksaan Diagnosis Laboratorium COVID-19: Keterbatasan dan Tantangannya Saat Ini
}

\author{
Wani Devita Gunardi \\ Departemen Mikrobiologi, Fakultas Kedokteran dan Ilmu Kesehatan, Universitas Kristen Krida \\ Wacana, Jakarta, Indonesia \\ Alamat Korespondensi:wani.gunardi@ukrida.ac.id
}

\begin{abstract}
Abstrak
Corona Virus Disease 19 (penyakit COVID-19) yang disebabkan oleh virus Corona pertama kali merebak di kota Wuhan di China pada akhir Desember 2019 dan masih berlangsung sampai dengan saat ini. Diagnosis COVID-19 biasanya didasarkan pada anamnesis riwayat perjalanan seseorang dari daerah pandemik, gejala klinis dan beberapa pemeriksaan laboratorium. Pemeriksaan laboratorium yang cepat dan spesifik sangat diperlukan untuk mempercepat penanganan atau mengendalikan kasus. Sampai saat ini metode pemeriksaan yang cepat dan akurat masih terus dikembangkan. Oleh karena itu, pada tulisan ini akan dibahas mengenai beberapa metode pemeriksaan COVID-19, kelebihan dan kekurangannya serta cara memilih metode pemeriksan yang tepat. Metode yang akan dibahas antara lain yaitu metode molekuler, imunoserologi, radiologi, rapid antigen, GeNose, dan metode lainnya seperti nano-biosensor dan CRISPR.
\end{abstract}

Kata Kunci: COVID-19, imunoserologi, tes molekuler

\section{Laboratory Diagnostic Tests for COVID-19: Current Limitations and Challenges}

\begin{abstract}
Corona Virus Disease 19 (COVID-19 disease) caused by the new Corona virus first broke out in the city of Wuhan in China at the end of December 2019 and is still ongoing today. Diagnosis of COVID-19 is usually based on travel histories from the pandemic area, clinical symptoms and some laboratory tests. Fast and specific laboratory tests are needed to speed up handling or controlling cases. Until now, a fast and accurate examination method is still being developed. Therefore, in this paper, we discuss several methods for diagnosing COVID-19, their advantages and disadvantages and how to choose the right examination method. The methods include molecular methods, immunoserology, radiology, rapid antigen, GeNose, and other methods.
\end{abstract}

Keywords: COVID-19, immunoserologi, molecular test 


\section{Pendahuluan}

Corona Virus Disease 2019 (penyakit COVID19) pertama kali merebak di kota Wuhan di China pada akhir Desember 2019 dan masih berlangsung sampai dengan saat ini. Awalnya, gejala penyakit COVID-19 ini menyerupai flu dan dicurigai penyebabnya virus influenza, virus pernapasan lainnya, Pneumoniae chlamydia dan Mycoplasma pneumoniae namun terbukti tidak satupun dari mikroorganisme tersebut ditemukan dalam pemeriksaan laboratorium. Hasil riset yang dilakukan dari sampel pasien memperlihatkan data sekuensing genom virus merupakan virus RNA baru yang memiliki hubungan dekat dengan famili Coronaviridae. Virus ini kemudian ditetapkan sebagai SARS-CoV-2 pada 11 Februari 2020. Temuan lainnya mengungkapkan bahwa virus ini memiliki $89 \%$ kesamaan genomik dengan virus corona pada kelelawar dan mirip virus SARS yang termasuk dalam subgenus Sarbecovirus dan Betacoronavirus. ${ }^{1}$

Virus Corona adalah sekelompok virus RNA berukuran besar (100-160 nm), berbentuk bulat, tidak tersegmentasi, berantai tunggal dengan genom berukuran 26-32 kb (yang terbesar di antara virus RNA yang diketahui), dan diketahui dapat menginfeksi hewan atau manusia. ${ }^{2-4}$ Virus Corona diklasifikasikan menjadi empat genera (aalfa, b-beta, c-gamma dan d-delta), dan hanya dua genera yang ditemukan pada manusia yaitu genera alfa yang terdiri dari CoVNL63 CoV-229E, dan genera-beta yang terdiri dari CoV-OC43, CoVHKU, MERS-CoV dan SARS-CoV., Genom virus COVID-19 sangat mirip dengan SLCoVZC45 yaitu strain kelelawar yang sudah dikenal dan SARS-CoV. ${ }^{1,6-7}$ Kelompok virus ini sangat mudah mengalami mutasi dan rekombinasi untuk menyesuaikan diri dengan lingkungan dan bertahan hidup melalui cara mengubah jangkauan target hospes yang lebih luas sehingga dapat menyebabkan ancaman terjadinya wabah. Oleh karena itu, dengan dasar pemahaman virologi dan cara mendeteksi yang tepat maka diupayakan pencegahan penyebaran penyakit COVID-19. ${ }^{8}$

Pendekatan klinis COVID-19 didasarkan pada anamnesis riwayat perjalanan seseorang dari daerah pandemik, gejala klinis dan untuk diagnosis didasarkan pada anamnesis dan beberapa pemeriksaan laboratorium serta pencitraan. ${ }^{9}$ Pemeriksaan diagnosis laboratorium COVID-19 yang cepat dan sensitif masih terus dikembangkan, meskipun saat ini telah tersedia beberapa metode untuk mendeteksi virus, materi genetik virus dan antibodi namun masing-masing metode tersebut memiliki keterbatasannya. Metode-metode yang selama ini dilakukan adalah melalui pendekatan deteksi virus atau materi genetiknya dan deteksi reaksi imunitas tubuh yaitu antibodi yang ditimbulkan sebagai respon imun terhadap antigen patogen penyebab. Untuk mendeteksi satu atau lebih materi genetik virus menggunakan metode Reversed Transcriptase-Polymerase Chain Reaction (RT-PCR), atau dengan Next Generation Sequencing yang mengurutkan genom utuh virus. Deteksi antibodi hasil respon imun pasien dilakukan atas dasar metode reaksi antigenantibodi seperti Enzyme Linked Immunosorbent Assay (ELISA). Metode-metode ini masingmasing memiliki kelebihan dan kekurangannya. Saat ini, World Health Organization (WHO) sudah menetapkan metode RT-PCR sebagai baku emas untuk mendeteksi materi genetik SARS-CoV-2 dan metode lainnya terus dikembangkan dan dievaluasi.

Dalam artikel ini, dibahas perkembangan metode pemeriksaan diagnosis laboratorium agar diagnosis COVID-19 dapat dilakukan dengan cepat, sederhana dan akurat. ${ }^{9}$ Selain itu juga akan membahas kelemahan dan kelebihan dari masingmasing metode serta cara memilih metode pemeriksaan yang tepat berdasarkan klinis dan waktu perjalanan penyakit serta kebutuhannya.

\section{Morfologi dan Struktur Genom SARS-CoV-2}

SARS-CoV-2 merupakan virus RNA baru dari famili Coronaviridae genus Betacoronavirus yang berukuran kurang lebih 70-90 $\mathrm{nm}$. Struktur virus ini berbentuk sperikal dan terdiri dari 4 protein struktural seperti protein spike (S), protein membran (M), selaput protein (E), dan protein nucleocapsid (N) (Gambar 1). ${ }^{10}$ Virus ini memiliki kekhasan berupa tonjolan-tonjolan pada permukaan virion yang menyerupai bentuk mahkota sehingga diberi nama virus Corona. ${ }^{11}$

Protein $S$ virus berfungsi untuk melekat pada Angiotensin Converting Enzyme 2 (ACE 2) yaitu reseptor dari sel inang (hospes) dan memediasi terjadinya infeksi. Protein M berukuran 25-30 kDa merupakan protein struktural yang terbanyak dalam virion dan berfungsi memberi bentuk virus. Protein E merupakan protein yang kecil dengan ukuran 8-12 kDa dan terdapat dalam jumlah kecil pada partikel virus. Protein E ini berfungsi dalam fasilitasi proses pembentukan dan pelepasan virus. Protein N merupakan satu-satunya protein yang berada dalam nukleokapsid heliks. ${ }^{10,11}$ 


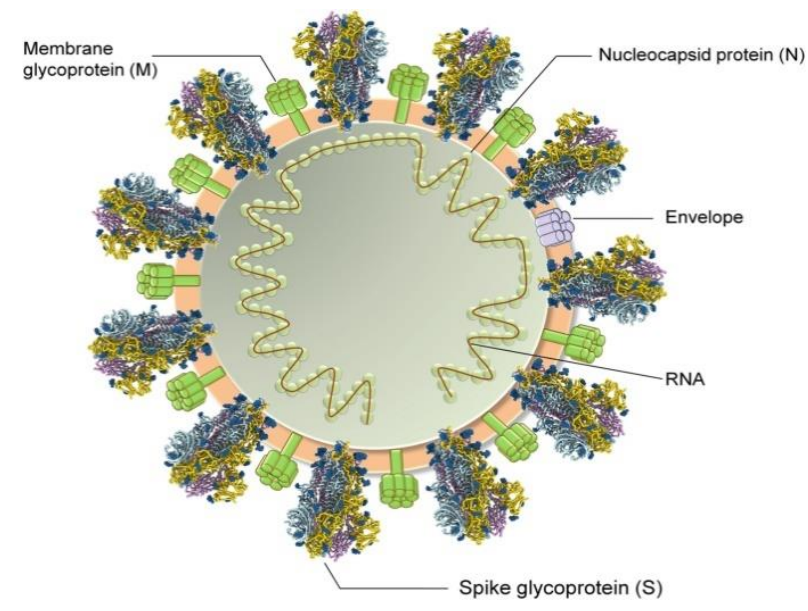

Gambar 1. Struktur SARS-CoV-2.

SARS-CoV-2 memiliki protein permukaan/surface viral proteins, yang bernama glikoprotein spike atau protein S, glikoprotein membrane atau protein $\mathrm{M}$, glikoprotein $\mathrm{E}$ atau selubung (envelope), dan glikoprotein $\mathrm{N}$ yaitu nukleokapsid helikal yang melindungi materi genetik (RNA) virus ${ }^{10}$

Genom virus corona berukuran antara 26 hingga $32 \mathrm{~kb}$ dan terdiri dari 6-11 Open Reading
Frame (ORF) yang menyandi 9680 poliprotein asam amino. ${ }^{12}$ ORF pertama terdiri dari sekitar $67 \%$ genom yang mengkode 16 protein nonstruktural (nsps), sedangkan ORF yang tersisa mengkodekan protein aksesoris dan struktural. Genom SARS-CoV-2 tidak memiliki gen hemaglutinin-esterase dan variasi urutan antara SARS-CoV-2 dan SARS-CoV tidak menunjukkan perbedaan yang signifikan pada ORFs dan nsps (Gambar 2). ${ }^{10}$

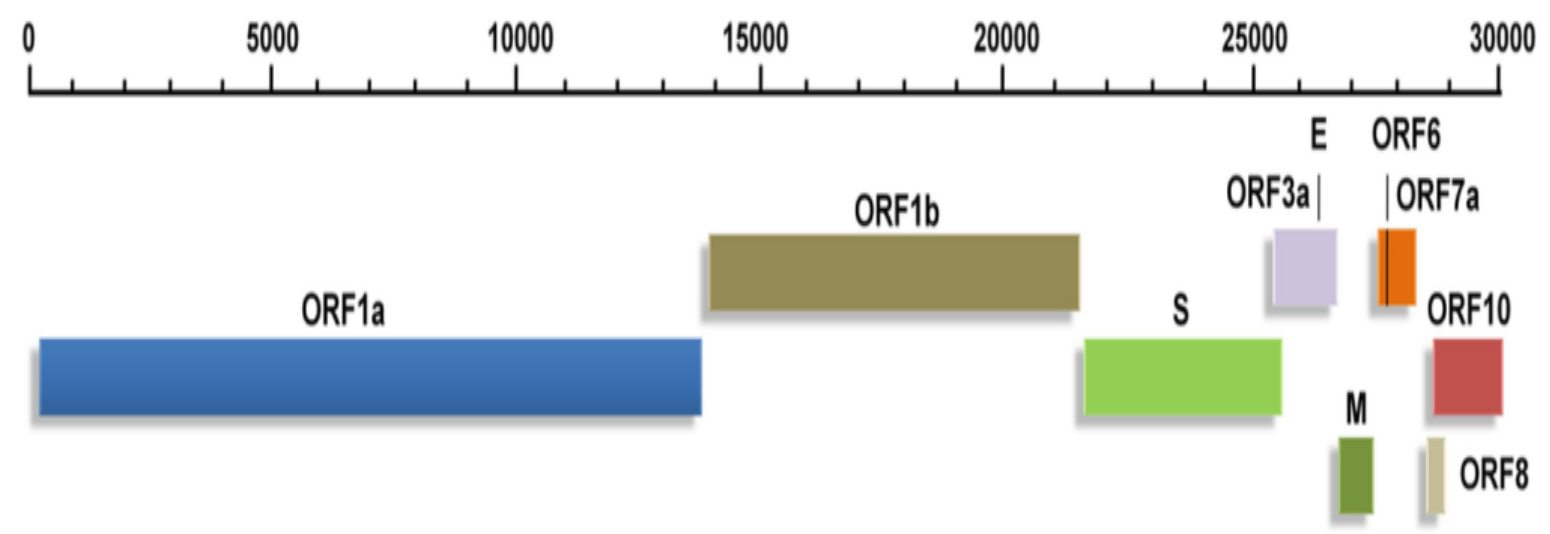

Gambar 2. Struktur genom SARS-CoV-2.

Ukuran genom virus corona berkisar antara 26 hingga $32 \mathrm{~kb}$ dan terdiri dari 6-11 kerangka baca terbuka (ORF) yang menyandikan 9680 asam amino poliprotein. ORF1a/b terdiri dari sekitar $67 \%$ genom yang mengkode 16 protein nonstruktural (nsps), sedangkan ORF yang tersisa mengkodekan protein aksesori dan struktural $^{10}$

\section{Metode Deteksi}

\section{a. Metode Molekuler}

Next generation sequencing (NGS) juga disebut sebagai High throughput sequencing (HTS). Metode ini dipakai untuk menentukan urutan genomik, digunakan lebih dari 1 juta pasang basa dalam satu kali pemeriksaan. Teknik ini, mampu mendiagnosis penyakit herediter, kanker, dan penyakit infeksi serta untuk melacak wabah 
Methicillin Resistant Staphylococcus aureus (MRSA) di rumah sakit. ${ }^{13,14}$ Metode ini memiliki akurasi yang tinggi dan pelacakan yang baik untuk menelusuri sumber penularan. Namun, penggunaan metode tersebut membutuhkan keahlian khusus dan biaya yang cukup mahal. ${ }^{14}$

Saat ini, quantitative RT-PCR (qRT-PCR) merupakan pemeriksaan yang umum digunakan untuk diagnosis COVID-19 dan merupakan baku emas untuk diagnostik molekuler dari berbagai jenis virus atau bakteri patogen yang fastidious. ${ }^{15}$ Kuantitatif RT-PCR memiliki beberapa kelebihan yaitu lebih spesifik, konsisten, dapat digunakan dengan mudah, hanya memerlukan primer-probe tertentu yang dirancang dan disintesis sesuai gen target. ${ }^{15,16}$ Setelah hasil primer virus SARSCoV-2 dari China dipublikasikan, alat tes diagnostik selain rRT-PCR dirancang dan dikembangkan para peneliti lainnya. ${ }^{9}$ Berbagai lembaga atau produsen telah memilih paduan gen target yang berbeda dari banyak gen SARS-CoV-2 (gen ORF1a, gen ORF-1b, gen RdRp, gen N, gen E dan lainnya), sehingga setiap alat tes memiliki variasi tingkat sensitivitas. Selain masalah sensitivitas yang bervariasi, qRT-PCR memiliki beberapa kelemahan seperti bahaya biosafety dan biosecurity yang mungkin terjadi selama pemrosesan sampel, transportasi, proses ekstraksi asam nukleat, dan kebutuhan peralatan laboratorium yang mumpuni untuk melakukan pemeriksaan qRT-PCR seperti kabinet biosafety, ruangan yang memiliki tekanan negatif dan peralatan pendukung lainnya. Peralatan dan standar ruangan harus dipenuhi, agar keamanan dan keselamatan petugas terjaga demikian juga kualitas mutu hasil pemeriksaan. ${ }^{16,17}$ Semua kelemahan tersebut harus dapat diatasi pada keadaan darurat kesehatan atau situasi wabah global seperti saat ini. Selain itu, alat PCR dapat digunakan untuk mendeteksi tidak hanya target virus, tetapi juga dapat melakukan deteksi beberapa virus pernapasan secara bersamaan yang menyebabkan peningkatan adanya risiko positif palsu atau negatif palsu. ${ }^{18}$

Loop-mediated isothermal amplification (LAMP) merupakan salah satu teknik molekuler yang relatif baru untuk diagnosis COVID-19. Metode ini juga menggunakan teknik amplifikasi molekuler yang dapat mendeteksi materi genomik dengan tingkat efisiensi tinggi dan waktu yang lebih singkat. Perbedaan LAMP dengan RT-PCR terletak pada suhu reaksi dan jumlah primernya. Pada LAMP sintesis DNA target dilakukan pada suhu konstan $60-65^{\circ} \mathrm{C}$ menggunakan enzim DNA polimerase dan empat primer yang dirancang khusus untuk mengenal sekuens DNA target. Penggunaan suhu konstan ini memperpendek durasi proses amplifikasi, sehingga durasi hasil tes dapat keluar lebih cepat dibandingkan metode PCR. Metode ini sangat spesifik dan memiliki sensitivitas yang tinggi, cepat dan lebih ekonomis. ${ }^{19,20}$

\section{b. Metode Deteksi Berbasis Reaksi Antigen- Antibodi/Imunoserologi}

Metode pengujian berbasis serologis biasanya mendeteksi virus sebagai antigen atau mendeteksi antibodinya dari sampel darah. Sampel darah mengandung konsentrasi antibodi atau antigen spesifik virus yang signifikan dan terukur. Dua jenis antibodi utama dalam darah yang dimaksud adalah imunoglobin $\mathrm{G}$ ( $\mathrm{IgG}$ ) dan imunoglobulin $\mathrm{M}$ (IgM). IgM muncul dalam beberapa hari dan bertindak sebagai sistim imun aktif yang pertama kali timbul, lalu diikuti oleh produksi IgG yang bekerja mengeliminasi infeksi. Tes darah untuk COVID-19 bertujuan mendeteksi protein (antigen/biomarker khas) atau antibodi khusus terhadap virus SARS-CoV-2 yang bersifat spesifik. $^{21}$

Rapid Antigen SARS-COV2 merupakan metode pemeriksaan imunoserologi dengan format tes alur lateral yang mudah digunakan dan umum dipakai untuk tes HIV, malaria, dan influenza. Antigen-Rapid Detection Test (Ag-RDT) biasanya terdiri dari kaset plastik dengan rongga sampel dan penyangga serta strip matriks nitroselulosa disertai penanda berupa garis uji. Target antigen akan terikat menjadi kompleks antigen-antibodi terkonjugasi. Target dari Ag-RDT biasanya berupa protein nukleokapsid virus yang berjumlah lebih banyak dari target antigen lainnya. Sampel yang dipakai untuk Ag-RDT adalah sampel usapan nasal atau nasofaringeal. Para peneliti terus melakukan penelitian agar dapat menggunakan jenis sampel alternatif seperti air liur, cairan oral, agar memudahkan pengambilan sampel sehingga mudah mendeteksi pelacakan kasus secara efisien dan efektif tanpa mengesampingkan kualitas mutu pemeriksaan.

Salah satu kelebihan metode Rapid Antigen SARS-COV2 yaitu tes lebih sederhana, mudah dilakukan, serta waktu pemeriksaan yang cepat sekitar 10-30 menit. Akan tetapi rapid antigen memiliki sensitivitas yang lebih rendah daripada metode molekuler. ${ }^{22}$ Hal tersebut didukung oleh studi yang dilakukan oleh Kosack et al. (2017) 
dalam mengevaluasi rapid antigen, yang menunjukkan bahwa sensitivitas uji cepat antigen lebih rendah dibandingkan dengan metode kultur dan metode molekuler. ${ }^{23}$ Hal tersebut dikarenakan uji cepat antigen memerlukan target jumlah virus tertentu untuk dapat terdeteksi antigen proteinnya sebagai hasil positif atau artinya, uji cepat antigen memiliki batas deteksi minimum jumlah virus. Beberapa penelitian lain juga menunjukkan bahwa sensitivitas Ag-RDT terhadap sampel dari saluran pernapasan atas (usap nasal atau nasofaringeal) tampak berbeda-beda jika dibandingkan NAAT, dengan rentang 0-94\% tetapi spesifisitasnya konsisten dilaporkan tinggi $(>97 \%)$. Berdasarkan hasil ini, maka pemeriksaan Ag-RDT dapat digunakan untuk telusur kontak pada kelompok kecil yang semi closed yaitu bilamana ditemukan hasil reaktif pada beberapa orang dalam kelompok tersebut. Hasil ini juga sebaiknya dikonfirmasi dengan pemeriksaan RT-PCR walaupun tidak merupakan prioritas. Sebaliknya bilamana didapati hasil negatif maka harus diprioritaskan untuk dilakukan pemeriksaan konfirmasi dengan RTPCR.

Sejumlah Point of Care Testing (POCT) berdasarkan IgM atau IgG yang didesain dengan prinsip imunokromatografi berbasis ELISA telah dikembangkan secara komersil. Uji ini mudah dilakukan, dan tidak memerlukan keahlian khusus untuk melaksanakannya serta dapat dengan mudah digunakan di lingkungan rumah sakit, di laboratorium atau di sisi tempat tidur pasien. Kit deteksi berbasis ELISA ini umumnya menggunakan antigen dari protein $\mathrm{N}$ dan protein $\mathrm{S}$ dan menunjukkan sensitivitas yang baik untuk SARS-CoV yaitu masing-masing 94,7\% dan 58,9\%. ${ }^{19}$ Akan tetapi, diagnosis berdasarkan antibodi kurang tepat bila digunakan pada saat awal infeksi COVID-19, karena antibodi baru terbentuk 7 hari atau lebih setelah infeksi virus atau setelah timbul gejala dan tidak dapat digunakan untuk memonitor pengobatan karena antibodi IgG akan terus bertahan setelah pasien sembuh. Metode POCT atau yang sering kita sebut uji cepat ini masih lazim digunakan karena uji ini dapat memberikan hasil dalam waktu 10-30 menit. $^{24}$

\section{c. Radiografi/CT-Scan}

CT Scan juga merupakan salah satu teknik diagnosis yang sensitivitasnya tinggi karena banyak peneliti merekomendasikan penggunaannya sebagai salah satu metode diagnostik tambahan yang diperlukan untuk mendiagnosis COVID-19. Hasilnya pun sudah dapat diketahui sebelum gejala klinis muncul. Gambaran umum CT dari pasien COVID-19 menunjukkan gambaran opak multi-lobar bilateral dengan distribusi yang berbeda di posterior dan juga di pinggiran, sub-pleura, septa lobular menebal dengan pengisian alveolar yang bervariasi, dan efusi. ${ }^{25,26}$

CT dada resolusi tinggi terbukti sebagai alat penting untuk mendeteksi SARS-CoV-2, pada tahap awal dan untuk mengambil tatalaksana intervensi yang cepat dan diperlukan. ${ }^{27}$ Oleh karena itu, berbagai penelitian baru-baru ini menggunakan gambar CT dada untuk menunjang diagnosis COVID-19. ${ }^{27-29}$ Gambar CT dada pasien yang terinfeksi COVID-19 bersifat khas. ${ }^{29}$ Sesuai temuan ini, CT scan ditemukan sebagai alat diagnostik yang bagus untuk skrining pasien COVID-19 terutama di daerah prevalensi atau pandemi yang tinggi. Akan tetapi CT scan hanyalah alat indikatif dan tidak dapat digunakan untuk mengonfirmasi patogen penyebab penyakit dalam diagnosis COVID-19. Terlebih lagi, CT scan juga memiliki beberapa kekurangan seperti ketidakmampuan untuk memisahkan kasus pneumonia lain (virus atau non-virus) dan histeresis pencitraan CT abnormal. ${ }^{9}$

\section{d. GeNose}

GeNose merupakan salah satu metode terbaru dalam mendeteksi infesi COVID-19 yang dikembangkan oleh peneliti dari salah satu universitas di Indonesia. Metode ini mendeteksi Volatile Organic Compound(VOC) yang terbentuk karena adanya infeksi COVID-19. VOC dikeluarkan bersama hembusan nafas ke dalam kantong khusus. Selanjutnya hembusan udara yang tertampung dalam kantong plastik akan diidentifikasi melalui sensor-sensor dan diolah datanya dengan bantuan kecerdasan buatan (Artificial Intelligence). Alat ini mampu mendeteksi dalam waktu kurang dari 2 menit. Sebelum diedarkan, alat ini dilakukan uji validasi untuk memetakan pola yang jelas dari COVID-19, dan pola dari orang-orang yang sakit non COVID19. Sampel uji validasi menggunakan 685 sampel napas dan di antaranya terdapat 382 sampel napas berpola COVID-19. Data 382 sampel napas berpola COVID-19 ini dijadikan sebagai data atau otak dari alat deteksi GeNose.

Hasil uji validasi dilanjutkan dengan uji klinik dan komparasi langsung dengan uji RT-PCR yang menjadi pemeriksaan baku emas untuk COVID-19. 
Uji klinis ini dilakukan di delapan rumah sakit dengan total sampel 1999. Hasil uji klinis menunjukkan bahwa alat ini memiliki sensitivitas antara $89-92 \%$ dengan spesifitas $95-96 \%{ }^{30}$

\section{e. Metode Lain Dalam Pengembangan}

Saat ini beberapa pendekatan diagnosis berbasis biosensor canggih telah banyak digunakan. Metode ini dapat mengatasi kelemahan deteksi PCR yang panjang. Salah satu biosensor yang paling banyak digunakan yaitu nanobiosensor. Nano-biosensor merupakan biosensor yang menggunakan aptamer, suatu alat analitik yang ampuh untuk diagnosis penyakit yang cepat dengan sensitivitas dan spesifisitas yang tinggi dengan cara yang efektif dan mudah penggunaannya dibandingkan dengan metode konvensional. ${ }^{31}$ Sensor nano semacam itu akan memiliki potensi besar untuk mendeteksi SARSCoV2 bahkan bagi yang tanpa gejala dengan sensitivitas, spesifisitas, dan selektivitas tinggi hanya untuk COVID-19. ${ }^{9}$

Perangkat berbasis kertas merupakan metode lain yang juga sedang dikembangkan untuk diagnosis COVID-19. Metode ini merupakan integrasi dari berbagai fungsi yang berbeda seperti untuk ekstraksi, elusi, pemurnian, amplifikasi dan deteksi, semua diproses dalam suatu jenis kertas, sekali pakai dan dicetak dengan lilin di permukaannya dalam bentuk zona. Perangkat tersebut diharapkan dapat menyelesaikan seluruh proses pengujian dengan sumber daya yang minimal, sehingga lebih bermanfaat daripada teknik lainnya yang mahal dan rumit. Perangkat analitik ini menggunakan metode microfluidisc berkualitas tinggi, cepat, dan tepat untuk deteksi, serta biaya produksi yang rendah dan mudah digunakan. ${ }^{32,33}$ Feses dan urin dari penderita COVID-19, juga merupakan limbah yang dapat mengandung virus, dan virus ini dapat tetap aktif di lingkungan yang sesuai selama beberapa hari. ${ }^{32,33}$ Hasil penelitian menunjukkan potensi kuat dari perangkat berbasis kertas ini untuk melacak penularan COVID-19 melalui air limbah di masyarakat melalui analisis SARS-CoV-2 dalam feses, urin dan ekskreta manusia lainnya. ${ }^{9}$

Metode lainnya yang sedang dikembangkan untuk mendiagnosis COVID-19 secara cepat ialah menggunakan CRISPR (Clustered Regularly Interspaced Short Palindromic Repeats). ${ }^{34}$ Sistem ini bekerja berdasarkan sistem imun yang adaptif dari bakteri terhadap genetik benda asing seperti faga. Prinsip yang digunakan adalah protein yang telah disiapkan khusus akan melekat pada target pilihan melalui RNA untuk pembelahan target sekuens. Beberapa protein yang dibuat seperti protein Cas13a yang bekerja pada RNA diharapkan akan lebih mudah untuk mendeteksi SARS-CoV$2 .^{35,36}$ Metode ini masih dalam proses pengembangan untuk dapat digunakan secara luas.

\section{Kelebihan Kekurangan Metode-Metode Deteksi ${ }^{19,37}$}

Tabel 1. Kelebihan Kekurangan Metode-metode Deteksi9,16,28

\begin{tabular}{|c|c|c|c|}
\hline Nama Metode & Prinsip & Kelebihan & Kekurangan \\
\hline $\begin{array}{l}\text { Next Generation } \\
\text { Sequencing } \\
\text { (NGS) }\end{array}$ & $\begin{array}{lr}\text { Whole } & \text { genome } \\
\text { sequencing } & \text { atau } \\
\text { pemetaan seluruh } \\
\text { genom virus }\end{array}$ & $\begin{array}{ll}\text { - } & \text { Sensitivitas dan } \\
& \text { spesifisitas sangat tinggi } \\
\text { - } & \text { Menampilkan semua } \\
& \text { informasi yang diperlukan } \\
\text { - } & \text { Dapat mengidentifikasi } \\
\text { strain baru }\end{array}$ & $\begin{array}{l}\text { - Memerlukan tenaga yang sangat } \\
\text { ahli } \\
\text { - Peralatan sangat mahal } \\
\text { - Diperlukan laboratorium yang } \\
\text { sangat canggih }\end{array}$ \\
\hline RT-qPCR & $\begin{array}{l}\text { Deteksi berdsarkan } \\
\text { Primer-Probe yang } \\
\text { spesifik }\end{array}$ & $\begin{array}{l}\text { - Hasil spesifik } \\
\text { - Membutuhkan DNA dalam } \\
\text { jumlah tidak terlalu banyak } \\
\text { - Dapat dilakukan dalam } \\
\text { tabung tunggal }\end{array}$ & $\begin{array}{l}\text { - Biaya tinggi karena penggunaan } \\
\text { bahan habis pakai mahal } \\
\text { - Deteksi peralatan lab mahal dan } \\
\text { kompleks } \\
\text { - Pemeriksaan memakan waktu } \\
\text { yang lama (ekstraksi RNA } \\
\text { memakan waktu lama) } \\
\text { - Sensitivitas kurang (viral load, } \\
\text { replikasi virus rendah, metode } \\
\text { isolasi virus dan waktu } \\
\text { pengambilan sampel terkait fase } \\
\text { penyakit mempengaruhi) } \\
\text { - Negatif palsu tinggi (perlu } \\
\text { dibarengi dengan pemeriksaan }\end{array}$ \\
\hline
\end{tabular}




\begin{tabular}{|c|c|}
\hline LAMP & $\begin{array}{l}\text { Deteksi } \\
\text { menggunakan dua } \\
\text { pasang atau lebih } \\
\text { pasang primer } \\
\text { spesifik }\end{array}$ \\
\hline
\end{tabular}

Serologi Antigen/Antibodies $\mathrm{IgG} / \mathrm{IgM}$

Rapid-Serologi Antigen/Antibodies $\mathrm{IgG} / \mathrm{IgM}$

$\begin{array}{ll}\text { Rapid Antigen } & \text { Antibodi/Antigen } \\ \text { GeNose } & \begin{array}{l}\text { Deteksi Volatile } \\ \text { Organic } \\ \text { Compound (VOC) }\end{array}\end{array}$

CT-Scan Gambaran paru

Isolasi atau Isolasi virus in vitro Kultur Virus dan propagasi virus
- Akurasi dan presisi tinggi

- Hanya menggunakan satu ukuran suhu sehingga tidak memerlukan thermocycler

- Hasil dapat keluar dalam waktu cepat

- Dapat mengukur kadar antibodi

- POCT

- Hasil dapat keluar dalam waktu cepat (15-20 menit)

- Waktu pemeriksaan singkat

Mudah

- Waktu pemeriksaan sangat singkat

- Tidak diperlukan keahlian untuk pengambilan sampelnya

Meningkatkan sensitivitas deteksi jika temuan dikombinasikan dengan hasil RT-PCR

Highly (100\%) specific Gold standard lain untuk kepastian seperti Ddimer dan absolute Limfosit Count)

- Sangat rentan terhadap positif palsu karena kontaminasi atau reaksi silang

- Tes dapat menunjukkan hasil positif 3-4 hari setelah infeksi

- Positif palsu

- Tes dapat menunjukkan hasil positif 3-4 hari setelah infeksi

- Positif palsu

- Pengambilan sampel memerlukan keahlian

- Sensitivitas lebih rendah dari metode kultur dan molekuler

- Belum digunakan secara luas

- Sensitivitas dan spesifisitas belum dievaluasi menyeluruh

Tidak dapat membedakan penyebab infeksi karena virus pneumonia lainnya dan hysteresis dari CT abnormal.

- Sensitivitas rendah

- Perlu peralatan yang canggih

- Perlu laboratorium yang sangat aman (BSL level 3)

- Perlu waktu yang sangat lama

\section{Pemilihan Metode yang Tepat}

Pemilihan metode yang tepat saat melakukan pemeriksaan laboratorium COVID-19 sangat perlu diperhatikan untuk menjamin ketepatan diagnostik dan pengobatan..$^{23,38}$ Hal-hal yang perlu diperhatikan saat melakukan pemilihan metode yaitu: tujuan dari dilakukannya pemeriksaan menjadi pertimbangan dalam melakukan pemilihan metode pemeriksaan. Pemeriksaan yang dilakukan apakah bertujuan untuk skrining, diagnostik atau monitoring pengobatan. Jenis metode yang digunakan dapat berbeda sesuai dengan tujuannya. ${ }^{23}$

Saat ini, infeksi COVID-19 memiliki gejala yang luas dan terkadang asimptomatik. Gambar 3 mendeskripsikan secara skematis respon antibodi terhadap infeksi SARS-COV-2. Berdasarkan gambar skematis tersebut, dapat digunakan untuk mendeteksi adanya infeksi SARS-CoV-2 dan perlu memperhatikan tahapan infeksi dan tujuan pemeriksaan. ${ }^{19}$ Apabila bertujuan untuk skrining atau penapisan, metode deteksi cepat menggunakan rapid test baik yang berbasis deteksi antibodi maupun yang berbasis deteksi antigen lebih cocok digunakan karena hasil lebih cepat dan pengambilan sampelpun lebih mudah. Akan tetapi bila bertujuan untuk mendeteksi atau mendiagnosis infeksi SARS-CoV-2 sebaiknya menggunakan metode molekuler yang lebih spesifik. Untuk pemeriksaan yang bertujuan monitoring pengobatan dapat digunakan metode berbasis reaksi antigen-antibodi seperti ELISA. ${ }^{24}$ 


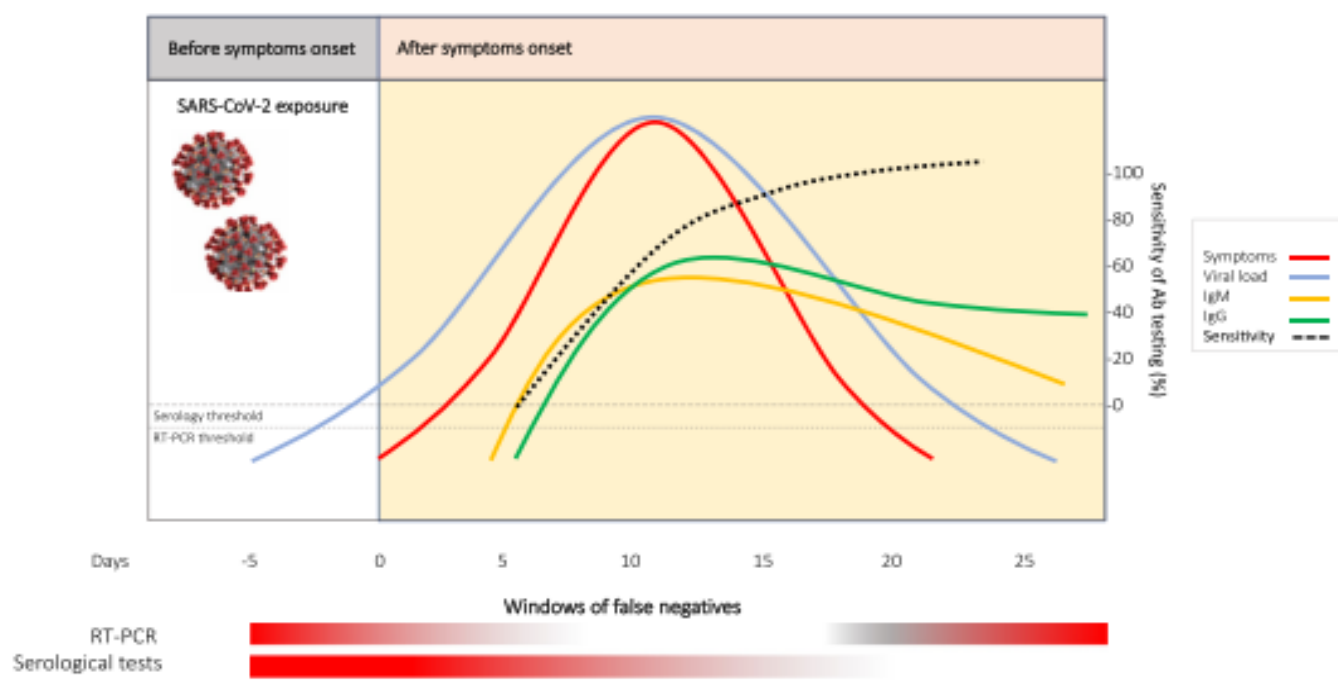

Gambar 3. Hubungan Waktu antara Viral Load, Gejala, dan Hasil Diagnosis Positif.

Munculnya gejala (0 hari) biasanya muncul 5 hari setelah infeksi $(0-5$ hari). Pada fase awal cenderung tidak timbul gejala, viral load berada di bawah batas threshold dari RT-PCR dan hasil tes kemungkinan bernilai negatif palsu. Hal yang sama juga terjadi pada fase akhir penyakit, ketika pasien pulih. Serokonversi biasanya terdeteksi 5-7 hari dan 14 hari setelah muncul gejala, sehingga pada fase pertama penyakit, tes serologi lebih sering memberikan hasil negatif palsu. Garis titiktitik warna hitam pada grafik mengilustrasikan sensitivitas dari chemiluminescent assay sebagai turunan dari data tes komersial (Abbot Diagnostics, USA)

Hal penting lainnya yang harus diperrhatikan saat memilih suatu metode ialah metode tersebut sudah disetujui atau dianjurkan oleh organisasi nasional seperti Kemenkes RI maupun organisasi internasional seperti FDA atau WHO serta sebaiknya memenuhi standar ISO $13485 .^{38}$ Selanjutnya, harus dilakukan evaluasi untuk meninjau performa pemeriksaan pada saat kondisi normal seperti melakukan proses penjaminan mutu internal sebelum alat tes digunakan untuk pemeriksaan rutin. Beberapa penelitian telah dilakukan untuk mengetahui akurasi sejumlah metode pemeriksaan baik tes serologi maupun molekuler. ${ }^{21-22,39}$ Semakin tinggi tingkat akurasi suatu metode makin baik.

\section{Penutup}

Pemilihan metode untuk pemeriksaan laboratorium COVID-19 harus memperhatikan beberapa aspek penting seperti tujuan pemeriksaan, akurasi tes, sensitivitas, spesifisitas, kemampuan laboratorium, lama pengerjaan, dan validasi hasil pemeriksaan. Selain itu harus diperhatikan juga kelebihan dan kelemahan yang dimiliki oleh masing-masing metode sehingga meminimalisir terjadinya kesalahan dalam mendiagnosis COVID-19. Hal ini perlu dilakukan karena COVID-19 sangat infeksius dan menyebar dengan cepat. Pemilihan metode yang tepat dapat mengurangi terjadinya risiko, penyebaran, penularan dan keparahan penyakit.

\section{Daftar Pustaka}

1. Wu F, Zhao S, Yu B, Chen Y-M, Wang W, Song Z-G, et al. A new coronavirus associated with human respiratory disease in China. Nature. 2020;579(7798):265-9.

2. Almeida JD, Tyrrell D. The morphology of three previously uncharacterized human respiratory viruses that grow in organ culture. Journal of General Virology. 1967;1(2):175-8.

3. Tok TT, Tatar G. Structures and functions of coronavirus proteins: molecular modeling of viral nucleoprotein. Int $\mathrm{J}$ Virol Infect Dis. 2017;2(1):001-7.

4. Van Der Hoek L, Pyrc K, Jebbink MF, Vermeulen-Oost W, Berkhout RJ, Wolthers $\mathrm{KC}$, et al. Identification of a new human coronavirus. Nature Medicine. 2004;10(4):368-73. 
5. Li F. Structure, function, and evolution of coronavirus spike proteins. Annual Review of Virology. 2016;3:237-61.

6. Su S, Wong G, Shi W, Weifeng S, Jun L, Alexander $\mathrm{C}$, et al. Epidemiology, genetic recombination, and pathogenesis of coronaviruses. Trends in Microbiology. 2016;24(6):490-502.

7. Drosten C, Günther S, Preiser W, Van Der Werf S, Brodt H-R, Becker S, et al. Identification of a novel coronavirus in patients with severe acute respiratory syndrome. New England journal of Medicine. 2003;348(20):1967-76.

8. Paules C, Marston H, Fauci A. Infeksi coronavirus - lebih dari sekedar pilek. JAMA. 2020;323(8):707-8.

9. Kumar R, Nagpal S, Kaushik S, Mendiratta S. COVID-19 diagnostic approaches: different roads to the same destination. VirusDisease. 2020:1-9.

10. Kumar S, Nyodu R, Maurya VK, Saxena SK. Morphology, genome organization, replication, and pathogenesis of severe acute respiratory syndrome coronavirus 2 (SARSCoV-2). Coronavirus Disease 2019 (COVID19): Springer; 2020. p. 23-31.

11. Shereen MA, Khan S, Kazmi A, Bashir N, Siddique R. COVID-19 infection: origin, transmission, and characteristics of human coronaviruses. Journal of advanced research. 2020;24:91-8.

12. Jin X, Lian J-S, Hu J-H, Gao J, Zheng L, Zhang $\mathrm{Y}-\mathrm{M}$, et al. Epidemiological, clinical and virological characteristics of 74 cases of coronavirus-infected disease 2019 (COVID19) with gastrointestinal symptoms. Gut. 2020;69(6):1002-9.

13. Harris SR, Cartwright EJ, Török ME, Holden MT, Brown NM, Ogilvy-Stuart AL, et al. Whole-genome sequencing for analysis of an outbreak of meticillin-resistant Staphylococcus aureus: a descriptive study. The Lancet Infectious Diseases. 2013;13(2):130-6.

14. Brown JR, Bharucha T, Breuer J. Encephalitis diagnosis using metagenomics: application of next generation sequencing for undiagnosed cases. Journal of Infection. 2018;76(3):225-40.

15. Afzal A. Molecular diagnostic technologies for COVID-19: Limitations and challenges. Journal of Advanced Research. 2020:149-59.

16. Corman VM, Landt O, Kaiser M, Molenkamp $\mathrm{R}$, Meijer A, Chu DK, et al. Detection of 2019 novel coronavirus (2019-nCoV) by real-time RT-PCR. Eurosurveillance. 2020;25(3):2000045.

17. Chu DK, Pan Y, Cheng SM, Hui KP, Krishnan $\mathrm{P}$, Liu Y, et al. Molecular diagnosis of a novel coronavirus (2019-nCoV) causing an outbreak of pneumonia. Clinical Chemistry. 2020;66(4):549-55.

18. Tang Y-W, Schmitz JE, Persing DH, Stratton CW. Laboratory diagnosis of COVID-19: current issues and challenges. Journal of Clinical Microbiology. 2020;58(6).

19. La Marca A, Capuzzo M, Paglia T, Roli L, Trenti T, Nelson SM. Testing for SARS-CoV2 (COVID-19): a systematic review and clinical guide to molecular and serological invitro diagnostic assays. Reproductive Biomedicine Online. 2020.

20. Nagamine K, Hase T, Notomi T. Accelerated reaction by loop-mediated isothermal amplification using loop primers. Molecular and Cellular Probes. 2002;16(3):223-9.

21. Bastos ML, Tavaziva G, Abidi SK, Campbell JR, Haraoui L-P, Johnston JC, et al. Diagnostic accuracy of serological tests for covid-19: systematic review and meta-analysis. BMJ. 2020:370.

22. Kubina R, Dziedzic A. Molecular and serological tests for COVID-19 a comparative review of SARS-CoV-2 coronavirus laboratory and point-of-care diagnostics. Diagnostics. 2020;10(6):434.

23. Kosack CS, Page A-L, Klatser PR. A guide to aid the selection of diagnostic tests. Bulletin of the World Health Organization. 2017;95(9):639.

24. Van Caeseele P, Bailey D, Forgie SE, Dingle TC, Krajden M, Network CPHL. SARS-CoV2 (COVID-19) serology: implications for clinical practice, laboratory medicine and public health. CMAJ. 2020;192(34):E973-E9.

25. Vogels CB, Brito AF, Wyllie AL, Fauver JR, Ott IM, Kalinich CC, et al. Analytical sensitivity and efficiency comparisons of SARS-COV-2 qRT-PCR assays. medRxiv. 2020.

26. Rodriguez-Morales AJ, Cardona-Ospina JA, Gutiérrez-Ocampo E, Villamizar-Peña R, Holguin-Rivera Y, Escalera-Antezana JP, et al. Clinical, laboratory and imaging features of COVID-19: A systematic review and metaanalysis. Travel Medicine and Infectious Disease. 2020:101623. 
27. Bernheim A, Mei X, Huang M, Yang Y, Fayad $\mathrm{ZA}$, Zhang $\mathrm{N}$, et al. Chest CT findings in coronavirus disease-19 (COVID-19): relationship to duration of infection. Radiology. 2020:200463.

28. Ajlan AM, Ahyad RA, Jamjoom LG, Alharthy A, Madani TA. Middle East respiratory syndrome coronavirus (MERS-CoV) infection: chest CT findings. American Journal of Roentgenology. 2014;203(4):782-7.

29. Ooi GC, Khong PL, Müller NL, Yiu WC, Zhou LJ, Ho JC, et al. Severe acute respiratory syndrome: temporal lung changes at thinsection CT in 30 patients. Radiology. 2004;230(3):836-44.

30. K SNS. Alat Tes COVID-19 GeNose UGM Diklaim 92 Persen Sensitif, Begini Risetnya. DetikHealthcom. 202028 Desember 2020.

31. Bagalkot V, Zhang L, Levy-Nissenbaum E, Jon S, Kantoff PW, Langer R, et al. Quantum dot- aptamer conjugates for synchronous cancer imaging, therapy, and sensing of drug delivery based on bi-fluorescence resonance energy transfer. Nano Letters. 2007;7(10):3065-70.

32. Chin A, Chu J, Perera M. Correspondence. Stability of SARS-CoV-2 in different environmental conditions. Lancet Microbe. 2020;1(1):e10.

33. Magro L, Escadafal C, Garneret P, Jacquelin $\mathrm{B}$, Kwasiborski A, Manuguerra J-C, et al.
Paper microfluidics for nucleic acid amplification testing (NAAT) of infectious diseases. Lab on a Chip. 2017;17(14):2347-71.

34. Barrangou R, Fremaux C, Deveau H, Richards $\mathrm{M}$, Boyaval $\mathrm{P}$, Moineau S, et al. CRISPR provides acquired resistance against viruses in prokaryotes. Science. 2007;315(5819):170912.

35. Liu Z, Dong H, Cui Y, Cong L, Zhang D. Application of different types of CRISPR/Casbased systems in bacteria. Microbial Cell Factories. 2020;19(1):1-14.

36. Makarova KS, Koonin EV. Annotation and classification of CRISPR-Cas systems. CRISPR. 2015:47-75.

37. Touma M. COVID-19: molecular diagnostics overview. Journal of Molecular Medicine. 2020:1-8.

38. Organization WH. Model list of essential in vitro diagnostics: (2018). World Health Organization, Geneva, Switzerland http://www who int/medical_devices/diagnostics/WHO_EDL_ 2018 pdf. 2018.

39. Liotti FM, Menchinelli G, Marchetti S, Morandotti GA, Sanguinetti M, Posteraro B, et al. Evaluation of three commercial assays for SARS-CoV-2 molecular detection in upper respiratory tract samples. European Journal of Clinical Microbiology \& Infectious Diseases. 2020;40(2):1-9. 